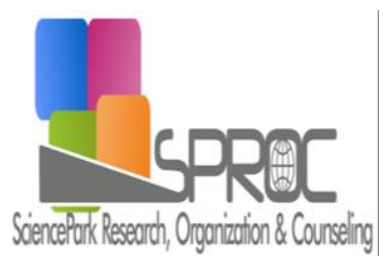

\title{
Co-constructing meanings in organizational development
}

Alexandra Galbin

Suggested Citation:

on Humanities and Social Sciences.

New Trends and Issues Proceedings

J

Abstract

sensemaking

J

Alexandra Galbin

E-mail address 
1. Introduction

ensemaking

2.On sensemaking

sensemaking 
but does not have a name

K

\section{References}

The handbook for teaching leadership

Revista de Cercetare si Interventie Sociala, 30

Academy of Management Journal, 47

$\mathrm{J}$

Leadership 4

$\mathrm{K} \quad \mathrm{K}$

knowledge
K

The social construction of reality: A treatise on the sociology of 
Organization Studies 36

Communication Yearbook, 13

Social constructionism

Revista de Cercetare si Interventie Sociala 29

Journal of Applied Behavioral Science, 45(3)

$\mathrm{K}$

Organization Studies 34

J

Never saw it coming: Cultural challenges to envisioning the worst

K

J

J

J

$\mathrm{K}$ Organization Science, 20

Revista de Cercetare si Interventie Sociala, 38

Appreciative inquiry in social work $\mathrm{K}$

Interventie Sociala 36

Revista de Cercetare si

J

Management Learning 45

Human Relations 65

J

Administrative Science Quarterly 49

Organization Science, 23

Principle-Centered Leadership: A Philosophy for Life and Success In Business $\mathrm{K}$

K

Journal of Management Studies 38

$\mathrm{K}$

Management Inquiry 11

Journal of

$\mathrm{K}$ 
si Interventie Sociala 30

$$
\mathrm{J}
$$

Academy of Management Review 24

Inteligenta materiei

$$
\mathrm{K}
$$

$\mathrm{K}$

Leadership

10

Organizational Behavior and Human Decision Processes

86

K

Advances in

experimental social psychology.

J Realities and relationships

J An invitation to social construction

J An invitation to social construction

J

K

K

The Sage Handbook of Organizational Discourse

$\mathrm{J}$

Journal of Public Administration, 24

International

$\mathrm{J}$

science

K

Playing with purpose. Adventures in performative social

$\mathrm{J}$

Management Science, 52

Process, sensemaking, and organizing

K

Journal of Management 21

Strategic Management Journal, 32

The social construction of organization

K

$P$

Strategic Management Journal, 32

$\mathrm{K}$

126

Psychological Bulletin,

K

Engaging communication in conflict: systemic practice

K

Journal of Management Studies 51 
$\mathrm{K}$

Marketing 26

K $\quad \mathrm{K} \quad \mathrm{K}$

Academy of Management Journal 51

K

Revista de Cercetare si Interventie Sociala 30

Career Development International, 6

Organization Studies 18

Journal 48

Academy of Management

The Academy of Management Annals 8

Journal of Management Studies 47

British Journal of Management 19

$\mathrm{J}$ 
Social psychology: Handbook of basic principle

Texts of identity $\mathrm{K}$

K

K Revista de Cercetare si Interventie Sociala, 38

53

Academy of Management Journal, J strategic management

The Palgrave encyclopedia of

surface

The emergent organization: Communication as its site and

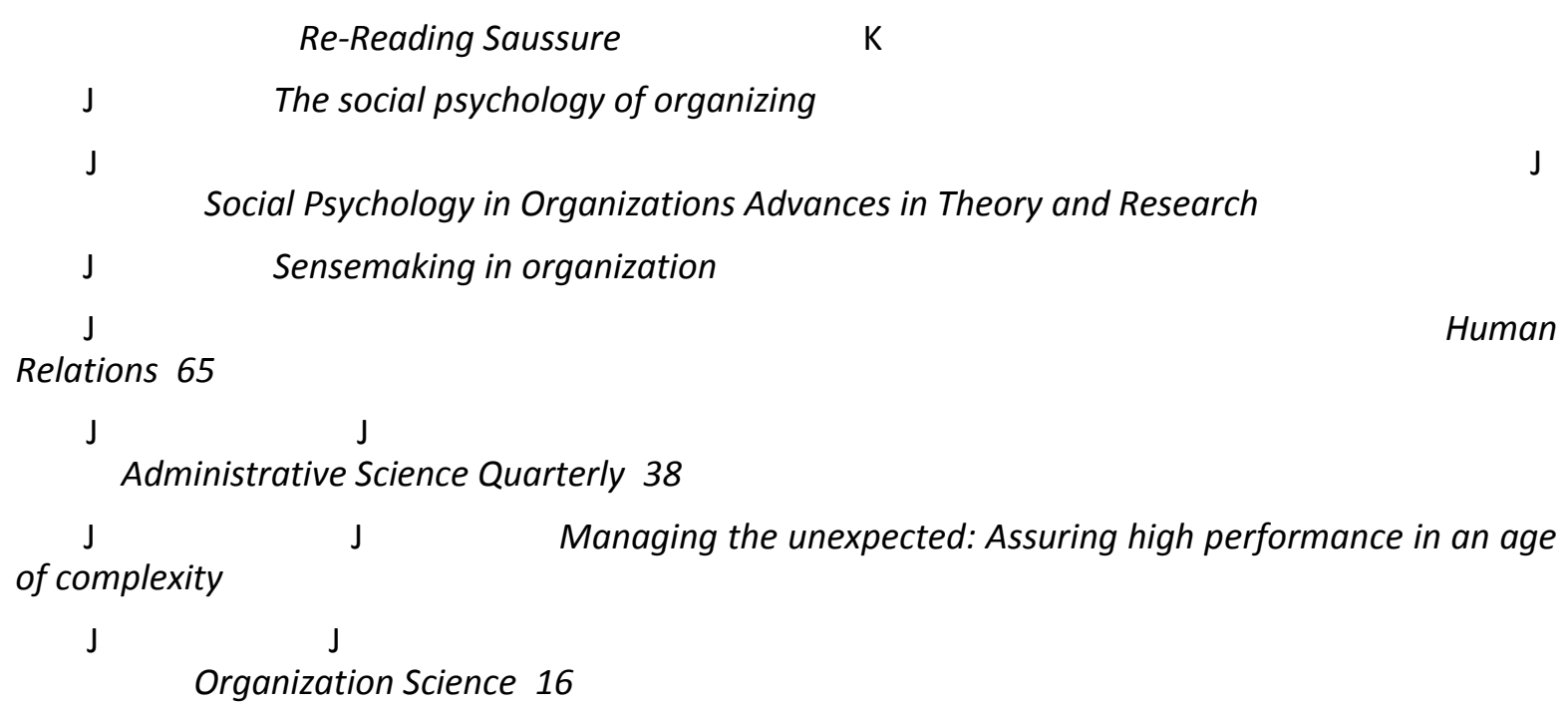

